\title{
Implementasi Teori Van Hiele Terintegrasi Teori Bruner Terhadap Hasil Belajar Matematika Siswa Kelas IV SDN 2 Rensing Tahun Pelajaran 2019/2020
}

\author{
Fitria Febrianti', Musabihatul Kudsiah ${ }^{2}$, Dina Afriana ${ }^{3}$, Mijahamuddin Alwi ${ }^{4}$, \\ Dina Fadilah ${ }^{5}$ \\ Program Studi Pendidikan Guru Sekolah Dasar Univesitas Hamzanwadi ${ }^{12345}$ \\ fitriafebrianti1214@gmail.com¹, musabihatul@gmail.com², \\ d33.nadhyn@gmail.com ${ }^{3}$, mijahamuddin.awi@gmail.com ${ }^{4}$, \\ dinafadilah29@yahoo.co.id ${ }^{5}$
}

\begin{abstract}
Abstrak
Penelitian ini bertujuan untuk mengetahui pengaruh implementasi teori Van Hiele terintegrasi teori Bruner terhadap hasil belajar matematika siswa kelas IV SDN 2 Rensing Tahun Pelajaran 2019/2020. Jenis penelitian yang digunakan adalah eksperimen dengan desain one group pretest-posttest design. Pengambilan sampel dilakukan dengan cara teknik sampling jenuh. Subjek penelitian ini adalah 22 siswa. Instrumen penelitian yang diberikan berupa tes essay. Uji prasyarat yang digunakan adalah Chi Kuadrat untuk menguji normalitas data, sedangkan uji $\mathrm{F}$ untuk menguji linieritas data. Berdasarkan hasil uji normalitas dan linieritas diperoleh bahwa populasi berditribusi normal dan linier. Berdasarkan hasil penelitian terlihat nilai rata-rata pretest 61,4 , sedangkan nilai rata-rata posttest 80,1 . Dari hasil perhitungan uji hipotesis yang menggunakan uji $t$ didapatkan hasil yaitu $t_{\text {hitung }}>t_{\text {tabel }}$ yakni 12,21 $>2,02$ dengan derajat kebebasan $(\mathrm{db})=42$, dengan taraf signifikansi 0,05. Dengan demikian $\mathrm{H}_{\mathrm{a}}$ diterima sedangkan $\mathrm{H}_{\mathrm{o}}$ ditolak. Hal ini menunjukkan bahwa implementasi teori Van Hiele terintegrasi teori Bruner berpengaruh terhadap hasil belajar siswa pada mata pelajaran matematika kelas IV.
\end{abstract}

Kata kunci : Teori Van Hiele, Teori Bruner, Hasil Belajar Matematika 


\section{PENDAHULUAN}

Pendidikan adalah bagian penting dari kehidupan manusia, melalui pendidikan seseorang dapat mengembangkan potensi yang ada dalam dirinya, dalam bentuk kegiatan bimbingan, pengajaran, dan latihan. Pendidikan merupakan suatu proses dalam rangka mempengaruhi siswa agar dapat menyesuaikan diri sebaik mungkin terhadap lingkungannya dan dengan demikian akan menimbulkan perubahan dalam dirinya yang memungkinkannya untuk berfungsi secara menyeluruh dalam kehidupan masyarakat (Hamalik, 2011: 79). Pengajaran bertugas mengarahkan proses ini agar sasaran dari perubahan itu dapat tercapai sebagaimana yang diinginkan.

Pendidikan pada jenjang sekolah dasar diselenggarakan dengan tujuan mengembangkan kemampuan dan keterampilan dasar yang diperlukan untuk hidup dan bermasyarakat. Untuk mencapai tujuan tersebut diperlukan pendidikan dan pengajaran dari berbagai disiplin ilmu. Salah satu disiplin ilmu tersebut adalah matematika. Matematika merupakan disiplin ilmu yang dapat meningkatkan kemampuan berpikir dan berargumentasi, memberikan kontribusi dalam penyelesaian masalah sehari-sehari dan dalam dunia kerja, serta memberikan dukungan dalam pengembangan ilmu pengetahuan dan teknologi. Kebutuhan akan aplikasi matematika saat ini dan masa depan tidak hanya untuk keperluan seharihari, tetapi terutama dalam dunia kerja, dan untuk mendukung perkembangan ilmu pengetahuan. Oleh karena itu, matematika sebagai ilmu dasar perlu dikuasai dengan baik oleh siswa, terutama sejak usia sekolah dasar (Susanto, 2013: 185).

Siswa sekolah dasar umurnya berkisar antara 6-7 tahun, sampai 12-13 tahun. Menurut Piaget, mereka berada pada fase operasional konkret. Dari usia perkembangan kognitif, siswa sekolah dasar masih terikat dengan objek konkret yang dapat ditangkap oleh panca indera. Dalam pembelajaran matematika yang abstrak, siswa memerlukan alat bantu berupa media, dan alat peraga yang dapat memperjelas apa yang akan disampaikan oleh guru, sehingga lebih cepat dipahami dan dimengerti oleh siswa (Heruman, 2014: 1).

Selama ini, guru belum banyak menerapkan model pembelajaran yang inovatif dalam proses pembelajaran di sekolah. Guru lebih suka mengajar dengan model pembelajaran yang berpusat pada guru (teacher centered instruction). 
Menurut Philip R Wallace (dalam Sunarto, 2009: 14) dalam pembelajaran ini guru mentransfer ilmu pengetahuan kepada siswa, sedangkan siswa lebih banyak sebagai penerima. Pembelajaran model tersebut biasa disebut dengan pembelajaran konvensional. Hal ini diungkapkan oleh Brooks dan Brooks (dalam Warpala, 2009: 12) "penyelenggaraan pembelajaran konvensional lebih menekankan kepada tujuan pembelajaran berupa penambahan pengetahuan, sehingga belajar dilihat sebagai proses 'meniru' dan siswa dituntut untuk dapat mengungkapkan kembali pengetahuan yang sudah dipelajari melalui kuis atau tes terstandar". Materi yang disampaikan juga tidak dihubungkan dengan pengalaman sehari-hari, sehingga siswa mudah lupa dan tidak dapat mengaplikasikannya. Selain itu, guru jarang menggunakan alat peraga dalam mengajar karena hanya menggunakan papan tulis sebagai media. Beberapa pertanyaan yang diajukan guru kepada siswa umumnya hanya untuk mengingat fakta dan bukan untuk memikirkan konsep.

Bruner melalui teorinya mengungkapkan bahwa dalam proses belajar anak sebaiknya diberi kesempatan memanipulasi benda-benda atau alat peraga dalam memahami suatu konsep matematika. Melalui alat peraga yang ditelitinya itu, anak akan melihat langsung keteraturan dan pola struktur yang terdapat dalam benda yang sedang diperhatikannya itu. Keteraturan tersebut kemudian oleh anak dihubungkan dengan intuitif yang telah melekat pada dirinya (Aisyah, 2007: 1-6). Sedangkan Van Hiele dalam teorinya mengungkapkan bahwa anak memahami geometri dengan pengertian, kegiatan belajar anak harus disesuaikan dengan taraf berpikirnya, di mana anak tidak dapat naik ke tingkat yang lebih tinggi tanpa melewati tingkat yang lebih rendah. Dengan demikian anak dapat memperkaya pengalaman dan berpikirnya, selain itu sebagai persiapan untuk meningkatkan tahap berpikirnya kepada tahap yang lebih tinggi dari tahap sebelumnya (Aisyah, 2007: 4-5).

Berdasarkan hasil observasi dan wawancara dari wali kelas IV SDN 2 Rensing. Ditemukan beberapa permasalahan-permasalahan yang diidentifikasi sebagai penyebab rendahnya hasil belajar, yaitu: (1) model pembelajaran konvensional, (2) pembelajaran yang berlangsung cenderung tidak melibatkan pengembangan siswa, karena guru selalu mendominasi pembelajaran (teacher centered), akibatnya proses pembelajaran sangat terbatas, sehingga kegiatan pembelajaran hanya diarahkan pada mengetahui (learning to know), ke arah 
pengembangan aspek kognitif dan mengabaikan aspek afektif dan psikomotorik, (3) dalam proses pembelajaran guru tidak mengajarkan konsep matematika sesuai dengan tahap perkembangan berpikir anak, (4) materi yang disampaikan juga tidak dihubungkan dengan pengalaman sehari-hari, sehingga siswa mudah lupa dan tidak dapat mengaplikasikannya, (5) masih banyak siswa yang sulit memahami pelajaran matematika khususnya materi geometri, dan (6) guru jarang menggunakan alat peraga dalam mengajar karena hanya menggunakan papan tulis sebagai media.

Oleh karena itu masalah-masalah tersebut perlu dicarikan suatu solusi agar pembelajaran yang dilaksanakan dapat meningkatkan hasil belajar matematika siswa. Salah satu upaya yang dilakukan untuk meningkatkan pemahaman konsep siswa pada materi geometri adalah dengan cara menerapkan teori Van Hiele terintegrasi teori Bruner. Teori Van Hiele merupakan tahap-tahap pemahaman siswa dalam geometri. Dalam mempelajari geometri, siswa mengalami perkembangan kemampuan berpikir melalui fase-fase tertentu. Fase-fase berpikir dalam mempelajari geometri menurut Van Hiele ada lima, yaitu fase informasi, fase orientasi, fase penjelasan, fase orientasi bebas, dan fase integrasi. Sedangkan teori Bruner terdapat tiga tahapan, yaitu tahap enaktif, tahap ikonik, dan tahap simbolis. Dalam implementasinya, fase informasi terintegrasi tahap enaktif, fase orientasi terintegrasi tahap ikonik, dan fase penjelasan terintegrasi tahap simbolis.

Dari uraian di atas maka dilakukan penelitian dengan judul "Implementasi Teori Van Hiele Terintegrasi Teori Bruner Terhadap Hasil Belajar Matematika Siswa Kelas IV SDN 2 Rensing Tahun Pelajaran 2019/2020“. Adapun tujuan dai penelitian ini adalah untuk mengetahui pengaruh implementasi teori Van Hiele terintegrasi teori Bruner terhadap hasil belajar matematika siswa kelas IV SDN 2 Rensing Tahun Pelajaran 2019/2020.

Teori Van Hiele merupakan tahap-tahap pemahaman siswa dalam mempelajari geometri. Dalam mempelajari geometri, siswa mengalami perkembangan kemampuan berpikir melalui tahap-tahap tertentu. Terdapat 5 tahapan yang harus berurutan dalam pembelajaran geometri yaitu tahap pengenalan, tahap analisis, tahap pengurutan, tahap deduksi, dan tahap keakuratan. Tahap pengenalan yaitu tahap dimana siswa mengenal geometri dan pada saat siswa menerima informasi pengetahuannya melalui pemahaman siswa dengan apa yang siswa lihat 
dan mengkomunikasikannya dengan menggunakan bahasa siswa. Tahap analisis adalah siswa mampu menyebutkan sifat-sifat dari geometri berdasarkan apa yang siswa lihat. Pada tahap pengurutan siswa sudah dapat mendeskripsikan secara deduktif tentang hubungan bangun satu dan yang lainnya. Tahap deduksi adalah tahap dimana siswa sudah dapat menarik kesimpulan dari apa yang siswa sebutkan pada tahap pengurutan. Sedangkan pada tahap keakuratan siswa sudah memahami prinsip-prinsip dasar suatu pembuktian. Untuk fase-fase pembelajaran geometri menurut Van Hiele ada 5 yaitu fase informasi, fase orientasi, fase penjelasan, fase orientasi bebas, dan fase integrasi.

Bruner, melalui teorinya itu mengungkapkan bahwa dalam proses belajar anak sebaiknya diberi kesempatan memanipulasi benda-benda atau alat peraga dalam memahami suatu konsep matematika. Melalui alat peraga yang ditelitinya itu, anak akan melihat langsung bagaimana keteraturan dan pola struktur yang terdapat dalam benda yang sedang diperhatikannya itu. Keteraturan tersebut kemudian oleh anak dihubungkan dengan intuitif yang telah melekat pada dirinya. Peran guru dalam penyelenggaraan pelajaran tersebut, (a) perlu memahami struktur mata pelajaran, (b) pentingnya belajar aktif supaya seorang dapat menemukan sendiri konsep-konsep sebagai dasar untuk memahami dengan benar, (c) pentingnya nilai berfikir induktif.

Dengan demikian agar pembelajaran dapat mengembangkan keterampilan inetelektual anak dalam mempelajari sesuatu pengetahuan (misalnya suatu konsep matematika), maka materi pelajaran perlu disajikan dengan memperhatikan tahap perkembangan kognitif/pengetahuan anak agar pengetahuan itu dapat diinternalisasi cara sungguh-sungguh (yang berarti proses belajar terjadi secara optimal) jika pengetahuan yang dipelajari itu dipelajari dalam tiga model tahapan yaitu tahap enaktif, ikonik, dan simbolis. Dimana pada tahap enaktif kita menyajikan siswa sesuatu yang nyata terkait materi pelajaran, kemudian tahap ikonik kita menyajikan siswa dalam bentuk gambar-gambar, dan tahap simbolis menggunakan lambanglambang bilangan.

Hasil belajar adalah perubahan yang mengakibatkan manusia berubah dalam sikap dan tingkah lakunya. Aspek perubahan itu mengacu kepada taksnomi tujuan pengajaran yang dikembangkan oleh Bloom, Simpson, dan Harrow mencakup aspek kognitif, afektif dan psikomotorik (Purwanto, 2013: 44) 
Matematika merupakan salah satu bidang studi yang ada pada semua jenjang pendidikan, mulai dari tingkat sekolah dasar hingga pergurun tinggi. Bahkan matematika diajarkan di taman kanak-kanak secara informal. Belajar matematika merupakan suatu syarat cukup untuk melanjutkan pendidikan ke jenjang berikutnya. Karena dengan belajar matematika, kita akan belajar bernalar secara kritis, kreatif, dan aktif. Matematika merupakan ide-ide abstrak yang berisi simbol-simbol, maka konsep-konsep matematika harus dipahami terlebih dahulu sebelum memanipulasi simbol-simbol itu (Susanto, 2013: 183).

\section{METODE PENELITIAN}

Jenis penelitian yang dilakukan dalam penelitian ini adalah penelitian eksperimen. Menurut Sugiyono (2013: 107) penelitian eksperimen yaitu penelitian yang digunakan untuk mencari pengaruh perlakuan tertentu terhadap yang lain dalam kondisi yang terkendalikan. Peneliti memberikan perlakuan (treatment) kepada subjek, sekelompok subjek atau partisipan atau kondisi, alat dan bahan tertentu untuk menentukan apakah perlakuan tersebut memiliki dampak atau pengaruh pada variabel atau faktor hasil tertentu (Setyosari, 2012: 41).

Adapun desain yang digunakan dalam penelitian ini adalah One-Group Pretest-Posttest Design (Sugiyono, 2013: 110). pengambilan sampel dalam penelitian ini menggunakan teknik sampling jenuh. Populasi dan sampel dalam penelitian ini dalah siswa kelas IV SDN 2 Rensing Tahun Pelajaran 2019/2020 yang berjumlah 22 orang.

Instrumen penelitian berupa tes essay yang terdiri dari 12 soal yang akan divalidasi. Penilaian terhadap jawaban tes dilakukan dengan menggunakan skala interval 1-4. Jawaban salah diberi skor 1, dan untuk skor 2, 3, dan 4 diberikan berdasarkan derajat ketepatan jawaban (Nurgiyantoro, 2017: 158). Sebelum memberikan tes, terlebih dahulu dilakukan uji coba tes untuk mengetahui validitas, reliabilitas, daya beda, dan tingkat kesuakaran suatu tes.

Teknik analisis data yang digunakan dalam penelitian ini adalah uji prasyarat analisis dan uji hipotesis. Uji prasyarat analisis berupa uji normalitas data dengan menggunakan rumus Chi-Kuadrat, dan uji linieritas data menggunakan rumus uji F. Sedangkan uji hipotesis menggunakan rumus uji-t. 


\section{HASIL DAN PEMBAHASAN}

Berdasarkan hasil penelitian diketahui bahwa implementasi teori Van Hiele terintegrasi teori Bruner memberikan pengaruh terhadap hasil belajar matematika siswa. Siswa yang diajarkan dengan teori Van Hiele terintegrasi teori Bruner memiliki hasil belajar lebih tinggi bila dibandingkan sebelum siswa belajar dengan teori tersebut. Selain itu juga perubahan atau hal positif yang didapat yaitu motivasi dan semangat siswa dalam belajar semakin tinggi, serta siswa dapat berperan aktif dalam proses pembelajaran.

Sebelum dilaksanakan pengambilan data pretest dan posttest maka instrumen terlebih dahulu diujicobakan kepada 20 orang siswa yang telah mempelajari materi pelajaran keliling dan luas segitiga dan jajargenjang. Uji instrumen yang dilakukan meliputi uji validitas, reliabilitas, daya beda, dan tingkat kesukaran yang masing-masing diterapkan pada soal tes berbentuk essay yang terdiri dari 12 soal. Hasil pengujian dari 12 soal tersebut adalah dai 12 soal ada 10 soal yang valid dan 2 soal tidak valid, hasil uji reliabilitas adalah rhitung > rtabel $(0,99>0,44)$ dengan keteia reliabilitas sangat tinggi, uji daya beda soal, dari 12 soal ada 4 soal dengan kriteria baik sekali, 6 soal dengan kriteria baik dan 2 soal dengan kriteria jelek, sedangkan hasi uji tingkat kesukaran adalah dai 12 soal terdapat 5 soal dengan kriteia mudah dan 7 soal dengan criteria sedang.

Perolehan nilai dari siswa dengan mengimplementasikan teori Van Hiele terintegrasi teori Bruner pada saat pretest, dari 10 soal yang diberikan diperoleh skor tertinggi 70 dan skor terendah 45 sehingga diperoleh skor rata-rata (mean) yaitu 61,4 sedangkan pada saat posttest dari 10 soal yang diberikan diperoleh skor tertinggi 90 dan skor terendah 65 sehingga diperoleh skor rata-rata (mean) yaitu 80,1.

Hasil pengujian normalitas, nilai pretest untuk hasil belajar menunjukkan bahwa $X^{2}$ hitung lebih kecil dari $X_{\text {tabel }}^{2}(2,237<9,488)$ dan nilai Posttest menunjukkan

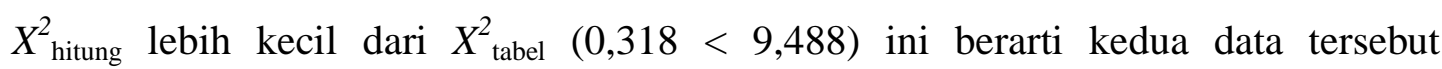
berdistribusi normal atau dalam sebaran normal. Sedangkan hasil perhitungan uji linieritas diperoleh $F_{\text {hitung }}(1,31)$ dan $F_{\text {tabel }}(3,01)$. Dengan kriteria yang ada yaitu $\mathrm{F}_{\text {hitung }} \leq \mathrm{F}_{\text {tabel }}$, maka dapat disimpulkan bahwa data yang diperoleh berpola linier.

Hasil pengujian hipotesis, ternyata hasil hipotesis alternatif (Ha) diterima. Pengujian hipotesis dalam penelitian ini menggunakan rumus t-test, dalam 
perhitungan statistiknya diperoleh $t_{h i t u n g}$ sebesar 12,21. Selanjutnya harga $t_{\text {hitung }}$ tersebut dikonsultasikan dengan $\mathrm{t}_{\text {tabel }}$ dengan taraf signifikasi $5 \%$ dengan $\mathrm{dk}=\mathrm{n}_{1}+\mathrm{n}_{2}$ $-2=22+22-2=42$, sehingga diperoleh $t_{\text {tabel }} 2,02$, maka $t_{\text {hitung }}>t_{\text {tabel }}$ yaitu 12,21 > 2,02. Hasil pengujian hipotesis adalah Ho ditolak dan Ha diterima. Sehingga penelitian yang telah dilaksanakan mendapatkan hasil bahwa ada pengaruh yang signifikan dari implementasi teori Van Hiele terintegrasi teori Bruner terhadap hasil belajar matematika siswa kelas IV SDN 2 Rensing.

\section{KESIMPULAN}

Berdasarkan data yang terkumpul dan hasil analisis yang telah dilakukan, maka dapat ditarik kesimpulan sebagai berikut: terdapat pengaruh yang signifikan dari implementasi teori Van Hiele terintegrasi teori Bruner terhadap hasil belajar matematika siswa kelas IV SDN 2 Rensing. Hal ini terlihat pada hasil analisis uji-t diperoleh $t_{\text {hitung }}(12,21)>t_{\text {tabel }}(2,02)$.

\section{DAFTAR PUSTAKA}

Aisyah, Nyimas, dkk. (2007). Pengembangan Pembelajaran Matematika SD. Jakarta: Depdiknas.

Hamalik, Oemar. (2011). Psikologi Belajar dan Mengajar. Bandung: Sinar Baru Algensindo.

Heruman. (2014). Model Pembelajaran Matematika Di Sekolah Dasar. Bandung: PT Remaja Rosdakarya Offset.

Nurgiyantoro, Burhan. (2017). Penilaian Pembelajaran Bahasa. Yogyakarta: BPFEYogyakarta.

Purwanto. (2011). Evaluasi Hasil Belajar. Yogyakarta: Pustaka Belajar.

Setyosari, Punaji. (2012). Metode Penelitian dan Pengembangan. Jakarta: Kencana Prenada Media Group.

Sugiyono. (2013). Metode Penelitian Kuantitatif Kualitatif dan $R \& D$. Bandung: Alfabeta

Sunarto, H. (2009). Perkembangan Peserta Didik. Jakarta: Depdikbud \& Rineka Cita. 
Susanto, Ahmad. (2013). Teori Belajar dan Pembelajaran di Sekolah Dasar. Jakarta: Prenadamedia Group.

Warpala, I.W.S. 2009. Pendekatan Pembelajaran Konvensional. Diunduh di http://edukasi.kompasiana.com/2009/12/20/pendekatanpembelajarankonvensi onal/ tanggal 5 Mei 2018. 